as increasing absenteeism (less than $10 \%$ of cases reported sick during school hours); it showed, over a week, a progression from younger to older pupils ; and it was quickly and decisively diagnosed.

How far these "symptom clusters" may be taken as of general application to the functional/organic distinction in school epidemiology only time and more evidence can decide. A simple deciding test is probably not yet within our reach. The $\mathbf{N}$ factor of the Eysenck Personality Inventory seems to discriminate between affected and non-affected populations in functional epidemics, but the $\mathrm{E}$ effect appears to be either unreliable or obtainable only under ideal conditions. And in the absence of control studies the usefulness of the $\mathrm{N}$ effect is debatable, for high $\mathrm{N}$ personalities may well have a low threshold for reporting organic illness.

A diagnostic category that is reached only by exclusion will collect all the errors made at earlier stages in the diagnostic process-and fall into disrepute. If diagnoses of epidemic hysteria are to inspire any confidence they must be made on positive grounds. Nevertheless, it does seem possible to collect positive data not only in the specially favourable case of mass admission to hospital but in the ordinary clinically undocumented instance.

\section{Summary}

Two school epidemics are contrasted: one at Portsmouth, probably functional, and one at Wrexham, due to Shigella sonnei. The Portsmouth epidemic satisfied criteria suggested previously for functional outbreaks. It occurred in a girls' school, and manifested almost exclusively in school hours. Its incidence showed a swing from older to younger classes with time on the day of maximum involvement ; it correlated with conduct disorders. The Wrexham epidemic, studied as a certainly organic control, did not satisfy these criteria.

The $\mathrm{N}$ scores, but not the $\mathrm{E}$ scores, of the Eysenck Personality Inventory, differentiated between affected. and unaffected populations in the Portsmouth epidemic.

We would like to thank the headmistresses of the schools involved for their co-operation, particularly Miss P. King, who uncomplainingly went to great trouble to meet a long list of requests.

The psychological side of these investigations was financed by a grant from the Clinical Research Committee of the Middlesex Hospital. We would like to thank Professor A. Kekwick and the Committee for their support and also Dr. A. W. Beard, consultant in psychological medicine at the Middlesex Hospital, for his interest and advice.

\title{
Return to Work after Myocardial Infarction
}

\author{
ELIZABETH A. WINCOTT,* A.I.M.s.w.; F. I. CAIRD,* D.M., M.R.C.P.
}

Four out of every five survivors of myocardial infarction at present return to work (Biörck and Wedelin, 1964 ; Biörck, 1964 ; Sharland, 1964). Little attention has been paid to the problems faced by these patients during their convalescence and return to work, except by Biörck (1959) and by Goble, Adey, and Bullen (1963), who emphasize the fact that disability is as often psychological as physical. The present investigation was designed to define these problems by means of a study of a group of men of working age who had had a myocardial infarct some months previously.

\section{Patients Studied}

A review was made of the case notes of all men under the sge of 70 who were discharged in 1964 from the Radcliffe infirmary with a diagnosis of myocardial infarction. There rere 98 such cases, and 25 of them were excluded at the outset -9 because there was no definite evidence of a recent myocardial infarct, 11 because they had died since discharge, 3 because they lived too far from Oxford, and 2 on account of other major disease. The general practitioners of the remainder

TABLE I.-Age Distribution
\begin{tabular}{|ll|c|c|c|c|c}
\hline Age &.. & $30-39$ & $40-49$ & $50-59$ & $60-69$ & Total \\
\hline Number &.. & 5 & 13 & 33 & 14 & 65 \\
\hline
\end{tabular}

were written to and were asked for permission for a medical social worker to visit their patients. Only two refused. The patients were then written to; only one would not agree to be visited, though five more did not reply to two letters. Table I shows the distribution by age of the remaining 65 men.

- The Radcliffe Infirmary, Oxford.
Six of the men were single, two were widowers, and one was separated. Sixteen had been admitted after their second myocardial infarct and one after his third.

The patients were visited at home by a medical social worker, who conducted a semi-structured interview lasting on average one and a half to two hours. Some specific questions were asked, but most of the interview consisted of open-ended questions, which allowed development in individual cases along particular lines. Table II shows the time after admission at which the patients were seen.

TABLE II.-Interval Between Aúmission and Intervicw

\begin{tabular}{cc|c|c|c|c|c|c|c}
\hline Months & $\cdots$ & $<6$ & $6-8$ & $9-11$ & $12-14$ & $15-17$ & $18+$ & Total \\
\hline Number & $\cdots$ & 0 & 8 & 15 & 20 & 13 & 9 & 65 \\
\hline
\end{tabular}

Table III.-Principal Problems Encountered

\begin{tabular}{|c|c|c|c|}
\hline & & During Convalescence & At Time of Interview \\
\hline $\begin{array}{l}\text { None . } \\
\text { Anxiety over job } \\
\text { Physical limitations } \ldots \\
\text { Fear of recurrence, etc. } \\
\text { Financial worries } \\
\text { Fear of dependence } \ldots \\
\text { Depression or anxiety } \\
\text { Miscellaneous }\end{array}$ & $\begin{array}{l}\because \\
\cdots \\
\cdots \\
\cdots \\
\cdots\end{array}$ & $\begin{array}{r}6 \\
30 \\
19 \\
15 \\
13 \\
5 \\
5 \\
11\end{array}$ & $\begin{array}{r}20 \\
13 \\
14 \\
19 \\
6 \\
17 \\
7 \\
11\end{array}$ \\
\hline
\end{tabular}

Results

Table III shows the principal problems encountered by the 65 men in the period immediately after the infarct and during convalescence, and those present at the time of interview. As might be expected, anxieties over employment and money, often related to the maintenance of a high standard of living and to 
meeting large financial commitments, were frequent during convalescence but less common later. Fourteen men were earning less after their infarct than before, and 22 were earning more, mostly as a result of general wage increases. Problems relating to physical limitations imposed by the disease or its management were also very common. Fear of recurrence with death or incapacity and fear of dependence on others were also frequent and persistent. Purely psychological symptoms of anxiety or depression were not common. Only four patients had a previous history of psychiatric disorder.

For 42 of the 56 married men there was adequate information about the influence of the myocardial infarct on sexual function. Sexual performance was affected in 17 men. In 13 cases sexual relations ended. Only four patients appear to have persisting angina associated with intercourse. The frequency of the problem is of course no measure of its importance to the individual.

Knowledge of coronary thrombosis, including that acquired from gossip and discussion with friends and acquaintances and from experience in hospital, had increased anxiety in 14 patients but had lessened it in 15 .

Only 11 patients (17\%) had cut down their leisure activities, such as gardening, fishing, or entertaining.

All but eight of the 65 men had returned to some employment. Of these eight, one was already retired at the time of his infarct, one aged 64 retired immediately after it, and one aged 57 retired from active farming. Of the 57 who returned to work $39(68 \%)$ returned to the same employment as before their infarct, and 18 to different jobs ; only one of these was with a different firm. Three of the four motor-vehicle drivers and 8 out of 11 workers in two large local car factories returned to different jobs within the same firm.

Fifty-eight per cent. of the men were back at work within 13 weeks, $83 \%$ within 27 weeks, and $88 \%$ within one year (Table IV). No obvious influences seemed to be hampering return to work. Patients had almost always regarded the attitude of employers and of family and friends as helpful. In Tables V-VIII a comparison is made between the 38 men returning to work within three months, the 19 returning after three months, and the 8 not at work. The presence of symptoms of ischaemic heart disease as recorded in the outpatient notes, the physical severity of their previous jobs, the possibility of part-time work, and the way in which the patient went back to work, whether initially part-time or to a light job, all bore no relation to the time of return to work. Patients who did

TABLE IV.-Time of Return to Work

\begin{tabular}{l|l|l|l|l|l}
\hline Weeks after admission: & 6 & 13 & 21 & 27 & 52 \\
\hline Number at work.. & 2 & 38 & 51 & 54 & 57 \\
Percentage at work.. & 3 & 58 & 78 & 83 & 88 \\
\hline
\end{tabular}

TABLE V.-Physical Symptoms and Return to Work

\begin{tabular}{|c|c|c|c|c|}
\hline & \multicolumn{2}{|c|}{ Return to Work } & \multirow{2}{*}{$\begin{array}{l}\text { Not at } \\
\text { Work }\end{array}$} & \multirow[b]{2}{*}{ Total } \\
\hline & $\begin{array}{l}\text { Within } \\
3 \text { Months }\end{array}$ & 3 After & & \\
\hline $\begin{array}{llr}\text { No symptoms } & \text {. } & . \\
\text { Angina and/or } & \text { dyspnoeea } \\
\text { Not known } & . . & . .\end{array}$ & $\begin{array}{r}15 \\
18 \\
5\end{array}$ & $\begin{array}{r}12 \\
7 \\
0\end{array}$ & $\begin{array}{l}2 \\
5 \\
1\end{array}$ & $\begin{array}{r}29 \\
30 \\
6\end{array}$ \\
\hline Total .. & 38 & 19 & 8 & 65 \\
\hline
\end{tabular}

not seem to have an entirely satisfactory relation with their general practitioner tended to return to work later (Table IX). Only four patients had difficulty with transport to and from work, though nine more had changed their mode of transport. Five out of nine patients who were in hospital for more than four weeks returned to work within 13 weeks.

There seemed to be no major factors assisting return to work. Forty-one patients had no contact with any social agency, and only 13 had seen a medical social worker at any time. Eight patients were unable to remember any advice given them during their stay in hospital, and $21(32 \%)$ could recollect no advice whatever given during visits to the hospital outpatient department.

The five patients who did not return to work at all had multiple problems. These mostly comprised severe physical symptoms, emotional problems, and difficulties in finding a suitable change of occupation, in some cases because they lived in rural areas.

TABLB VI.-Severity of Work Before Infarct

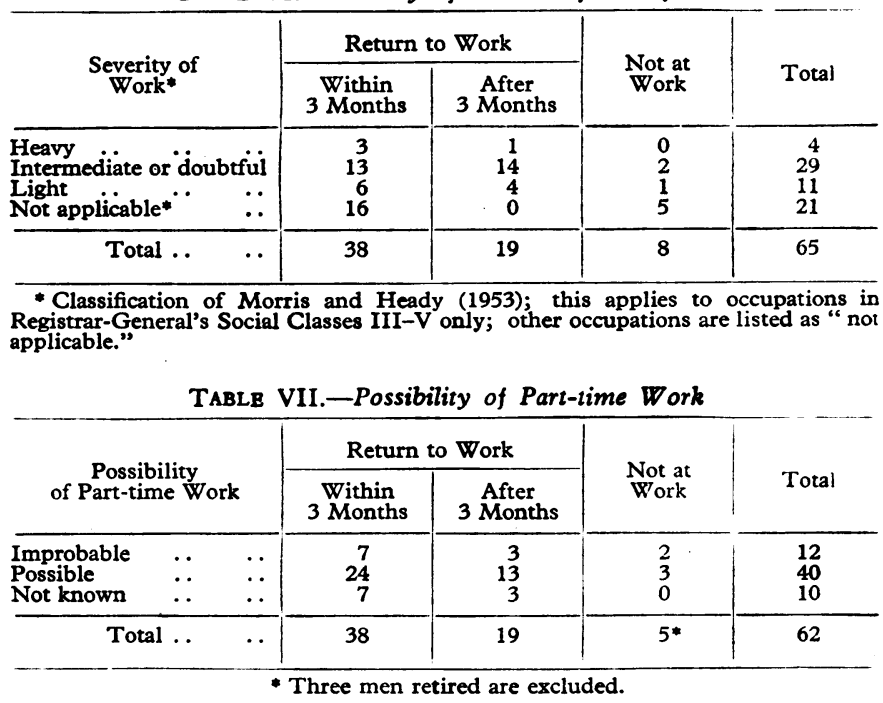

TABLE VIII.-Mode of Return to Work

\begin{tabular}{|c|c|c|c|}
\hline \multirow{2}{*}{ Mode of Return to Work } & \multicolumn{2}{|c|}{ Return to Work } & \multirow{2}{*}{ Total } \\
\hline & Within 3 Months & After 3 Months & \\
\hline 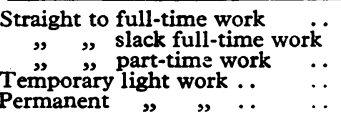 & $\begin{array}{r}13 \\
11 \\
8 \\
5 \\
1\end{array}$ & $\begin{array}{l}7 \\
5 \\
2 \\
3 \\
2\end{array}$ & $\begin{array}{r}20 \\
16 \\
10 \\
8 \\
3\end{array}$ \\
\hline Total $\quad$. & 38 & 19 & 57 \\
\hline
\end{tabular}

TABLE IX.-Relation with General Practitioner

\begin{tabular}{|c|c|c|c|c|}
\hline \multirow{2}{*}{$\begin{array}{c}\text { Relation with } \\
\text { General Practitioner }\end{array}$} & \multicolumn{2}{|c|}{ Returned to Work } & \multirow{2}{*}{$\begin{array}{l}\text { Not at } \\
\text { Work }\end{array}$} & \multirow[b]{2}{*}{ Total } \\
\hline & $\begin{array}{l}\text { Within } \\
3 \text { Months }\end{array}$ & 3 Months & & \\
\hline $\begin{array}{l}\text { Satisfactory } \\
\text { Less than Satisfactory }\end{array}$ & $\begin{array}{l}28 \\
10\end{array}$ & $\begin{array}{r}8 \\
11\end{array}$ & $\begin{array}{l}7 \\
1\end{array}$ & $\begin{array}{l}43 \\
22\end{array}$ \\
\hline Total .. & 38 & 19 & 8 & 65 \\
\hline
\end{tabular}

\section{Discussion}

The patients in this study are selected by admission to hospital, by survival for several months, by agreement to co-operate in the investigation, and, most important, by living and working in or near Oxford. Nevertheless, they are probably typical of men of working age who survive a myocardial infarct. Eightyeight per cent. returned to work, a proportion much like those found by Sharland (1964) and Biörck (1964), despite considerable differences in the composition of the groups studied. Fourteen out of $16(88 \%)$ returned to work after their second infarct. The comparable figure in Biörck and Wedelin's (1964) study is 17 out of $28(61 \%)$. The outlook for return to work is thus no less good for the survivors of a second than for those of a first infarct.

Fifty-eight per cent. of the men were at work within three months of admission and $83 \%$ within six months (Table IV). 
These figures are almost identical with those of Sharland (1964). In general the failure to find any obvious difference between patients who returned to work within three months and those who returned after three months suggests the predominance of indefinable or irrational factors. Those of importance may well be the attitudes of doctors, employers, and patients. Tables VI and VII show, however, that part-time or temporary light work is available and already used to "take the heat off" in the ürst months after a myocardial infarct (Brit. med. F., 1964).

Our findings agree with those of Biörck and Wedelin (1964) that social agencies, as at present deployed, contribute comparatively little to the rehabilitation of these patients. Twothirds had had no contact with any social agency whatever. Two-thirds of those who returned to work do so to their original occupations (Biörck, 1964). In some cases a change of occupation seems to have been due not to any physical strain of the work done but to a combination of the case with which such a change may be possible within a larger firm and the stresses of long hours of piecework.

Difficulties with transport to and from work may well be much commoner among patients living and working in large sities than in the patients studied here. Certainly conditions of transport in London can prevent patients with ischaemic heart disease from getting to and from work which would be well within their physical capabilities.

Goble et al. (1963) describe in graphic detail how in patients with myocardial infarction psychological disability can be initiated and perpetuated by experiences in hospital and by failure of subsequent medical management, so that it may become more crippling than the physical symptoms of ischaemic heart disease. The most important psychological factor is undoubtedly fearin particular, fear of recurrence and invalidism and of dependence on others, with loss of the man's role as head of and provider for the family (Table III).

The main remedy for the social and psychological problems arising after myocardial infarction must lie in detailed attention to them from a very early stage of the illness. The added psychological problems created by coronary-care units are discussed by Goble, Sloman, and Robinson (1966). The increasingly accepted reduction to a minimum of bed rest may well bring more psychological than physical benefits. Mobilization can be accompanied by an optimistic attitude, looking forward to increasing activity and return to work within a matter of weeks, rather than to prolonged and slow convalescence. Such an attitude can be entirely justified by the facts (Biörck, 1964 ; Sharland, 1964 ; Table IV). These facts can well be used in explanation to the patient. The patient's wife should also receive the necessary courtesy of similar explanation. Many wives have more anxieties than their husbands (Goble et al., 1963).

Prompt communication between doctor and patient, hospital and general practitioner and factory doctor, and doctor and employer, is likely to reduce delays in return to work. Frequent attendance at hospital outpatient department should be unnecessary. Only five patients in the present study were on longterm anticoagulants, and indeed the waning popularity of this treatment may well result in lessening of patients' anxieties. In this study the only example of drug dependence of psychological origin was to quinidine given to prevent palpitations.

Both the individual and the community might derive greater economic benefit if the comparatively small proportion of patients who do not at present return to work after a myocardial infarct did so than if the much larger number who do return did so earlier. The small numbers in the present study who did not return to work (12\%) do not permit of any useful conclusions, except to confirm the finding of Goble et al. (1963) that such patients usually have multiple problems. Of these problems the physical, represented by the symptoms of ischaemic heart disease, are not effectively susceptible to prevention or treatment; the social, such, for instance, as difficulties over employment, may require retraining, which is often difficult for men in later middle life ; but the psychological are likely to be lessened by the early initiation of an active and optimistic approach to management.

\section{Summary}

Sixty-five men under the age of 70 were interviewed some months after admission to hospital for myocardial infarction: $88 \%$ had returned to work-38 (58\%) within three months and a further 19 in the next three months. These two groups did not differ in any material way.

During convalescence anxieties over employment and finance predominated, and at a later stage fear of recurrence, invalidism, and dependence on others. An active and optimistic approach to rehabilitation is advocated in order to prevent these problems.

Our thanks are due to the physicians of the Radcliffe Infirmary and the general practitioners for permission to study patients under their care ; to the medical officers of the Pressed Steel Co. and the British Motor Corporation; and to Drs. J. R. A. Mitchell, F. A. Bevan, and C. A. S. Wink, and Miss A. E. Turner (principal medical social worker, Radcliffe Infirmary), for their helpful advice and criticism.

\section{REPERENCES}

Biörck, G. (1959). Amer. Heart f., 58, 414

(1964). F. chron Dis., 17, 653.

and Wedelin, E. M. (1964). Acta med. scand., 175, 215.

Brit. med. F., 1964, 2, 703.

Goble, A. J. Adey, G. M., and Bullen, J. F. (1963). Mod. ₹. Aust., 2, 975 .

- Sloman, G., and Robinson, J. S. (1966). Brit. med. f., 1, 1005.

Morris, J. N., and Heady, J. A. (1953). Brit. F. industr. Med., 10, 245.

Sharland, D. E. (1964). Brit. med. F., 2, 718. 